\title{
Phenology and growth of lulo (Solanum quitoense Lam) plants grafted onto Solanum hirtum Vahl.
}

\section{Fenología y crecimiento de plantas de lulo (Solanum quitoense Lam) injertadas sobre Solanum hirtum Vahl.}
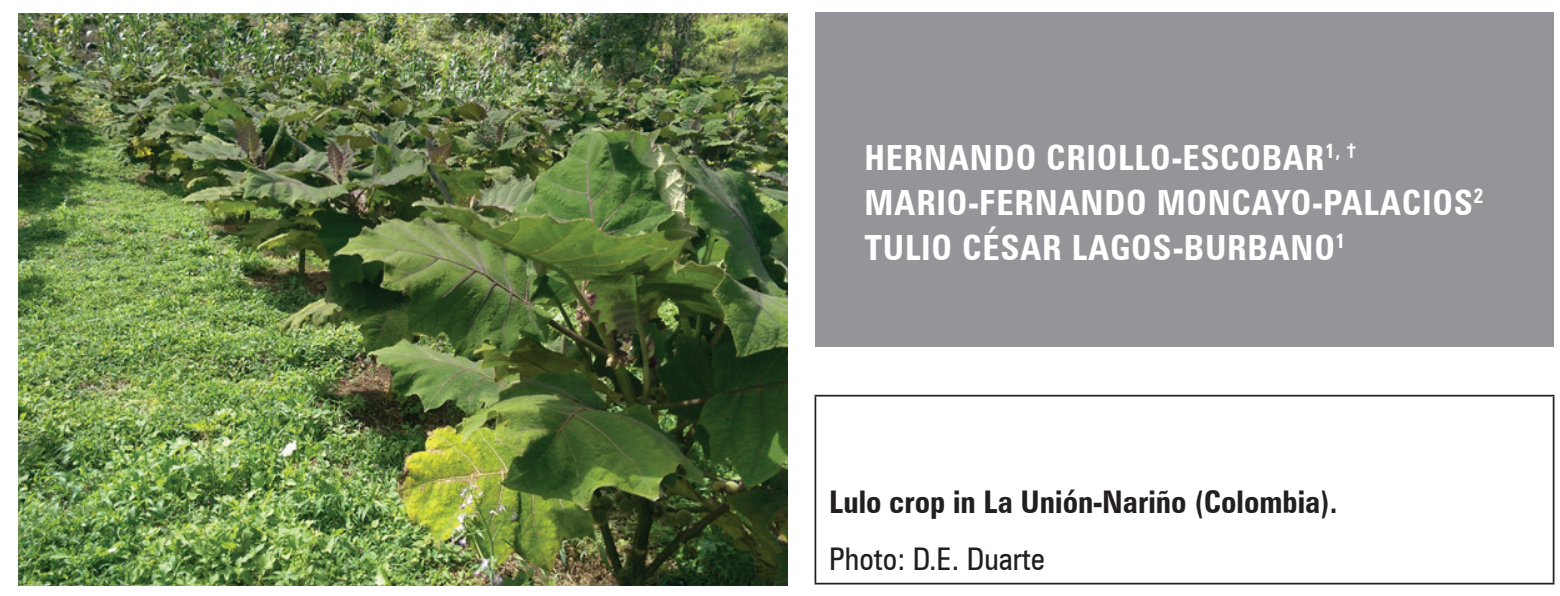

\section{ABSTRACT}

Lulo (Solanum quitoense) is a promising Andean fruit tree that is highly valued in international markets because of its nutritional characteristics, flavor, aroma, and high content of vitamins $\mathrm{A}$ and $\mathrm{C}$ with antioxidant properties. However, certain sanitary problems, such as Fusarium oxysporum and soil nematodes, pose challenges to the competitiveness of lulo crops. Cultivating lulo plants grafted onto resistant patterns, such as $S$. hirtum, is a plausible solution to these sanitary issues; so, determining the behavior of grafted plants is relevant. In this study, the phenology and growth dynamics of grafted lulo plants were evaluated with functional analyses based on thermal time (degree days-DD). Completion of the vegetative phase of the lulo required $561 \mathrm{DD}$ from planting to the onset of flower bud sprouting, $715 \mathrm{DD}$ to reach anthesis, $801 \mathrm{DD}$ for fruit set, and a cumulative total of 2,464 DD to reach fruit ripening. The functional analyses showed that Richards's model fit the dynamics of the growth variables (height, leaf area index, crop growth index, total dry weight, leaf dry weight, and stem dry weight). Of the total plant dry biomass, $39.7 \%$ corresponded to the stems, $33.8 \%$ was from the fruits, $15.54 \%$ was from the leaves, $10.56 \%$ was from the roots, and $0.4 \%$ was from the flowers. The yield was not affected by the grafting process of lulo $S$. quitoense onto S. hirtum stocks; on the contrary, the crop population and productivity were maintained for a longer time.

\footnotetext{
Additional key words: plant phenology; functional analysis; day-degrees; allometry; partition.

1 Universidad de Nariño, Faculty of Agriculture Sciences, Grupo de Investigación en Producción de Frutales Andinos (GPFA). San Juan de Pasto (Colombia). ORCID Criollo-Escobar, H.: 0000-0002-8690-4486; ORCID Lagos-Burbano, T.C.: 0000-0001-9222-4674

2 Universidad de Nariño; Servicio Nacional de Aprendizaje (SENA), Cartago (Colombia). ORCID Moncayo-Palacios, M.-F.: 0000-0001-7200-309X

3 Corresponding author.tclagosb@udenar.edu.co
} 


\section{RESUMEN}

El lulo (Solanum quitoense) es un prometedor árbol frutal andino muy apreciado en los mercados internacionales por sus características nutricionales, su sabor y aroma, y su alto contenido de vitaminas A y C con propiedades antioxidantes. Sin embargo, ciertos problemas sanitarios, como Fusarium oxysporum y nematodos del suelo, plantean problemas para la competitividad del cultivo del lulo. Al respecto, el cultivo de plantas de lulo injertadas en patrones resistentes, como S. hirtum, es una solución plausible a estos problemas sanitarios y, por lo tanto, determinar el comportamiento de las plantas injertadas es una cuestión relevante. En este estudio se evaluó la fenología y la dinámica de crecimiento de las plantas de lulo injertadas mediante análisis funcionales basados en el tiempo térmico (grados día-DD). La finalización de la fase vegetativa del lulo requirió 561 DD desde la plantación hasta el inicio de la brotación del botón floral, $715 \mathrm{DD}$ para alcanzar la antesis, $801 \mathrm{DD}$ para el cuajado de los frutos y un total acumulado de 2.464 DD para alcanzar la maduración de los frutos. Los análisis funcionales mostraron que el modelo de Richards se ajustaba a la dinámica de las variables de crecimiento (altura, índice de superficie foliar, índice de crecimiento del cultivo, peso seco total, peso seco de la hoja y peso seco del tallo). Del total de la biomasa seca de la planta, el 39,7\% correspondía a los tallos, el 33,8\% a los frutos, el $15,54 \%$ a las hojas, el 10,56\% a las raíces y el 0,4\% a las flores. El rendimiento no se vio afectado por el proceso de injerto de lulo $S$. quitoense en $S$. hirtum; por el contrario, la población de los cultivos y su productividad se mantuvieron durante más tiempo.

Palabras clave adicionales: fenología vegetal; análisis funcional; grados-día; alometría; partición.

Received for publication: 14-05-2020 Accepted for publication: 23-11-2020

INTRODUCTION

In Colombia, the total crop area for lulo (Solanum quitoense Lam.) in the productive stage in 2018 was $8,821.3$ ha with a production of $89,050 \mathrm{t}$ of fruits and an average yield of $10.09 \mathrm{t} \mathrm{ha}^{-1}$. In the same year, the Department of Huila was the highest producer, with 14,340 t, followed by Valle del Cauca, Antioquia, Boyaca, and Cauca (Agronet, 2020). Lulo is one of the most promising fruit crops for the Andean region, thanks to its good organoleptic characteristics and unique aptitude for the agro-industry (Gallo et al., 2018).

Lulo is susceptible to sanitary issues that limit crop production and cause high losses for producers. Therefore, creating disease-tolerant plants is necessary for ambitious exportation projects (Criollo et al., 2014). Also, the lulo production system has severe limitations associated with technological, phytosanitary, and commercial factors that threaten sustainability (Muñoz et al., 2013). According to Muñoz (2010), the main problems in lulo crops are Meloidogyne incognita, which affects water and nutrient uptake, Neoleucinodes elegantalis, which perforates fruits and induces premature fruit drop, Colletotrichum gloesporioides, which causes fruit rotting, Sclerotinia sclerotiorum or cottony soft rot, Phytophthora sp., which leads to dark lesions in the leaves and stems, defoliation, and plant death, and Fusarium oxysporum, which affects roots and causes plant death (Noboa and Viera, 2020; Benítez et al., 2020).

Grafting fruit tree species, such as lulo, is a promising technique used for the vegetative propagation of outstanding plants, in which the rootstock is diseasetolerant or resistant (Rojas et al., 2004). Considering the resistance of several wild Solananceae species to Fusarium oxysporum and Meilodigine incognita (Arizala et al., 2011; Clements et al., 2016; Navarrete et al., 2018; Vargas et al., 2018). There are studies on lulo plants grafted onto resistant rootstocks, such as Solanum hirtum; however, the behavior of these grafts and their implications on crop productivity and fruit quality are unknown.

An important aspect when evaluating grafted lulo plants is the rhythm of the appearance of vegetative and reproductive structures, which depends on the interaction of biotic and abiotic factors (Browning et al., 2019). According to Casiano and Paz (2018), anthropic and climatic effects can cause variations in growth patterns and the appearance of plant structures. Thus, site growth conditions, such as climate, soil and plant management, can affect the duration of phenological stages (Fischer and Melgarejo, 2020). 
The flowering stage is the most sensitive. Luo et al. (2015) stated that the ambient temperature affects crop growth, development, and production since there are specific temperature requirements to complete each stage of the life cycle. Lulo crops show adequate development in zones with temperatures of $15-24^{\circ} \mathrm{C}$, with an optimum of $20^{\circ} \mathrm{C}$ (Sánchez-Reinoso et al., 2019). Water and energy balance are also significantly affected by temperature (Sacks and Kucharika, 2011).

To determine the effects of the environment and genetic composition of plants on biomass accumulation, techniques with plant growth analysis are needed to accurately estimate productivity variables with simple measurements, such as leaf area (LA), leaf area index (LAI), crop growth index (CGI), and biomass (Poorter and Sack, 2012). According to Di Benedetto and Tognetti (2016), evaluating crop growth in response to agronomic modifications, such as grafting, requires growth analysis techniques that can be statistically validated.

The growth rate of different plant structures largely determines the partition of assimilates and plant productivity. The balance between the energetic demand of plant organs and the photosynthetic contribution of plants must be considered. The efficiency of this partition will affect the composition of the total biomass and, particularly, the distribution of photosynthates to commercially-important organs (Ochoa-Vargas et al., 2016). Crop production seeks to enhance conditions for longer periods of high productivity, with efficient partitioning, achieved with an adequate source-sink relationship (Barrientos et al., 2015). This study aimed to analyze the crop phenology, growth dynamics, and yield of lulo (Solanum quitoense var. quitoense) plants grafted onto Solanum hirtum plants.

\section{MATERIALS AND METHODS}

The study was conducted on the Instituto Educativo de Desarrollo Rural I.E.D.R Farm, in the municipality of La Union, Nariño, located at an elevation of $1,782 \mathrm{~m}$ a.s.1., at $1^{\circ} 35^{\prime} 15^{\prime \prime} \mathrm{N}$ and $77^{\circ} 07^{\prime} 32^{\prime \prime} \mathrm{W}$, with an average temperature of $19.32^{\circ} \mathrm{C}$, average relative humidity of $78 \%$, and total cumulative precipitation of $1,512.6 \mathrm{~mm}$.

The soil of the experimental plot was composed of volcanic ash and sand with a pedological content of
70\% Typic Hapludands and 30\% Typic Fulvudansds, characterized by a first horizontal layer to a depth of more than one meter (González and Salamanca, 2008). The soil analysis showed adequate contents of organic matter $(3.28 \%)$, potassium $\left(0.43 \mathrm{cmol} \mathrm{kg}^{-1}\right)$, and minor elements (in $\mathrm{mg} \mathrm{kg}^{-1}: \mathrm{Mn}=6.8, \mathrm{~B}=0.6$, $\mathrm{Fe}=26.72, \mathrm{Zn}=2.1$, with a slightly acidic $\mathrm{pH}(5.6)$; low contents of calcium $(2.3 \mathrm{cmol} \mathrm{kg-1})$, magnesium (1.2 $\left.\mathrm{mg} \mathrm{kg}^{-1}\right)$, and phosphorus (16.43 $\mathrm{mg} \mathrm{kg}^{-1}$ ); apparent density $\left(1.09 \mathrm{~kg} \mathrm{dm}^{-3}\right)$, sandy loam texture, and $17 \%$ slope.

The plant material was produced by grafting lulo de castilla (S. quitoense var. quitoense) onto S. hirtum rootstocks. When the $S$. hirtum plants reached a diameter of 8-10 $\mathrm{mm}$, they were cut at a height of $10 \mathrm{~cm}$ and grafted with $S$. quitoense twigs that were tied with plastic tape and covered with a plastic bag for 1 week to prevent dehydration. After 1 month, the plants were transferred to the field. The grafted plants were sown in $0.3 \times 0.3 \times 0.3 \mathrm{~m}$ holes, arranged in five rows of 13 plants each with a distance of $3 \mathrm{~m}$ between rows and $2 \mathrm{~m}$ between plants. The planting density was 1,666 plants/ha. $80 \mathrm{~g}$ of dolomite lime were added to each hole, and $1.2 \mathrm{~kg}$ of organic matter were added to each hole ( $20 \mathrm{~d}$ before planting).

Plant nutrition was guaranteed through bimonthly fertilizer applications after planting with urea, DAP (diammonium phosphate) as a source of phosphorus and nitrogen, and potassium chloride as a source of potassium. For the first application, $15 \mathrm{~g}$ urea $+12 \mathrm{~g}$ DAP were mixed; after two months, 25 g urea +20 g KCL (potassium chloride) + 15 g DAP were used, with a third application of $30 \mathrm{~g}$ urea $+30 \mathrm{~g}$ KCL +20 $\mathrm{g}$ DAP. The subsequent applications consisted of $40 \mathrm{~g}$ urea $+35 \mathrm{~g} \mathrm{KCL}+25 \mathrm{~g}$ DAP.

Phenological analyses were performed by evaluating the thermal time, which indicated the degree-days (DD) necessary for the grafted lulo plants to change their phenological stage. The DD was calculated with the difference between the mean daily temperature and a base temperature $(T b)$ of $9.61^{\circ} \mathrm{C}$ (Matzarakis et al., 2007; Pulido et al., 2008) (Eq. 1):

$$
\mathrm{DD}=\sum\left(\frac{T \max +T \min }{2}-\mathrm{Tb}\right)
$$

The growth was evaluated every month in two plants select randomly, measuring their height and dry weight of the root, stem, leaves, flowers, and 
fruits. The leaf area (LA) was calculated based on 100 measurements of lulo leaves, following the method proposed by Rincón et al. (2012), using ImageJ and fitting them to a regression model with CurveExpert, with equation $2\left(R^{2}=0.97\right)$ :

$$
L A=133.05-7.35 x+0.85 x^{2}
$$

This information was used to calculate the leaf area index (LAI), which is the ratio between the LA and the ground area occupied by the plant (Criollo et al., 2019) (Eq. 3).

$$
\mathrm{LAI}=\left(\frac{L A}{\mathrm{GA}}\right)
$$

Similarly, the crop growth index (CGI) was calculated based on the model proposed by Aguilar-Campo et al. (2015), modified by the thermal time (Eq. 4):

$$
\text { CGI }\left(\mathrm{g} \mathrm{m}^{-2} \mathrm{DD}^{-1}\right)=\frac{\mathrm{TDW}_{2}-\mathrm{TDW}_{1}}{\mathrm{DD}_{2}-\mathrm{DD}_{1}} \times \frac{1}{\mathrm{GA}}
$$

where, $T D W_{1,2}$ is total dry weight at the beginning and end of the stage, $D D_{1,2}$ is the thermal time of the interval, and $G A$ is the ground area $\left(\mathrm{m}^{2}\right)$.

The yield was estimated based on the weight of ripe fruits at harvest ( $85 \%$ orange in color on the surface) produced by four selected plants during a period of eight harvests, evaluated every $15 \mathrm{~d}$. All variables, except for those related to phenology, were functionally analyzed to evaluate their dynamics based on the cumulative thermal time throughout the plant life cycle. Behavioral models for the lulo grafts were selected according to the highest $R^{2}$ values and lowest deviations. Models were determined using CurveExpert v 1.4.

\section{RESULTS AND DISCUSSION}

\section{Phenology and thermal time}

Onset of flowering in the grafted lulo plants, which is determined by the appearance of the first flower buds, required $561 \mathrm{DD}$ from the moment of planting. This requirement is very similar to the one found by Cruz et al. (2007) under greenhouse conditions, with a value of $528 \mathrm{DD}$, indicating a difference of approximately $3 \mathrm{~d}$. The flower opening stage, or anthesis, required $715 \mathrm{DD}$ from the moment of planting, which indicated a requirement of $154 \mathrm{DD}$ to transition from flower bud to open flower in grafted plants. This requirement agrees with Muñoz (2010), who estimated a thermal time of $723 \mathrm{DD}$ to reach anthesis, indicating that the grafting process did not affect the thermal time requirement. However, Viteri et al. (2006) reported that grafted plants showed higher precocity in flowering than non-grafted plants, demonstrating that the degree of maturity of the grafted buds and the interaction between different environmental conditions, such as high temperature, high soil humidity, quality and quantity of solar radiation and genotype, can affect the ontogenetic stages of the plants (Silva et al., 2015; Serna, 2017).

Fruit set required $86 \mathrm{DD}$ after anthesis, contributing to a cumulative total of $801 \mathrm{DD}$ from planting. This confirmed that the propagation of lulo de castilla with grafts does not affect the thermal time requirement for fruit set. The results of this study agrees with Jurado et al. (2013), who did not report statistically significant differences between the time required for fruit set in $S$. quitoense and $S$. quitoense grafted onto Solanum spp.; furthermore, fruit set was not influenced by the rootstock.

The S. quitoense fruits reached harvest maturity when thermal time reached 2,464 DD. The transition from fruit set to ripening had the highest thermal time requirement $(1,663 \mathrm{DD})$, which may have been due to environmental conditions such as an average temperature of $19.47^{\circ} \mathrm{C}$, a thermal amplitude of $11^{\circ} \mathrm{C}$, a relative humidity of $74 \%$ and a precipitation of 893.5 $\mathrm{mm}$. These conditions delay the ontogenetic period of harvest maturity. The duration of each stage, as opposed to the need for thermal time, can vary depending mainly on temperature, radiation and soil humidity (Medina et al., 2008).

\section{Functional growth analyses}

Plant height (PH). The growth analysis showed individuals with heights of $1.70 \mathrm{~m}$ at the end of the evaluation $(2,464 \mathrm{DD})$. The growth dynamics of $\mathrm{PH}$ were fitted to Richards model with an $R^{2}=0.98$ (Fig. 1); this model did not require destructive methods because it visualized the behavior of growth and other variables (López-Cruz et al., 2005) based on thermal time. This behavior agrees with the results of Arizala et al. (2011), who showed similar dynamics in grafted lulo plants. 
Figure 1A shows that, by the end of the evaluation, the increase in plant height was less marked because of the architecture of the plants. In particular, plant growth is vertical during the first stages, whereas, during development, growth is redirected towards the secondary stems in the search for greater solar radiation interception.

Leaf area index (LAI). The LAI reached its highest value by the end of the evaluation, 1.13. This index increased slowly at first, yet, after 1,000 DD, it rose rapid and ended at 2,400 DD. The LAI trend was fit to Richards model with an $R^{2}=0.99$ (Fig. 1B). These results agree with Taiz et al. (2017), who confirmed that, in the first growth stages, there was little development of the leaf area, resulting in a low LAI. A higher LAI can improve the physiological behavior of a plant by increasing the area of solar radiation interception and photosynthetic production. Similarly, Almanza et al. (2008) evaluated the LAI dynamics in S. quitoense plants in response to different fertilizers, demonstrating that fertilization can affect this variable positively, i.e. the higher the fertilization, the higher the LAI.
Crop growth index (CGI). Figure 1C shows the dynamics of the CGI, which had an initial value of $0.03 \mathrm{~g} \mathrm{~m}^{-2} \mathrm{DD}^{-1}$. This result was explained by plant stress from the grafting process, which caused slow growth in leaf area and biomass. After that, a period of rapid growth was observed until 2,681 DD, reaching a CGI of up to $8.79 \mathrm{~g} \mathrm{~m}^{-2} \mathrm{DD}^{-1}$. At this point, the CGI decreased to $1.37 \mathrm{~g} \mathrm{~m}^{-2} \mathrm{DD}^{-1}$ at $3,252 \mathrm{GD}$. The CGI behavior was fitted to a Gaussian model with an $R^{2}=0.95$.

The CGI reached a maximum thermal time of 2,681 DD when the LAI was 1.0. This was followed by a reduction that was likely due to overshading from adjacent plants with wide and uneven leaf coverage that could not be controlled in the experiment area, which can affect photosynthetic efficiency and biomass accumulation. A high CGI indicates a greater efficiency of biomass production per unit of soil. In this sense, Jerez et al. (2016) stated that CGI is an index of agricultural productivity for which high values indicate high production of organs of interest for harvesting, contributing to higher yield.
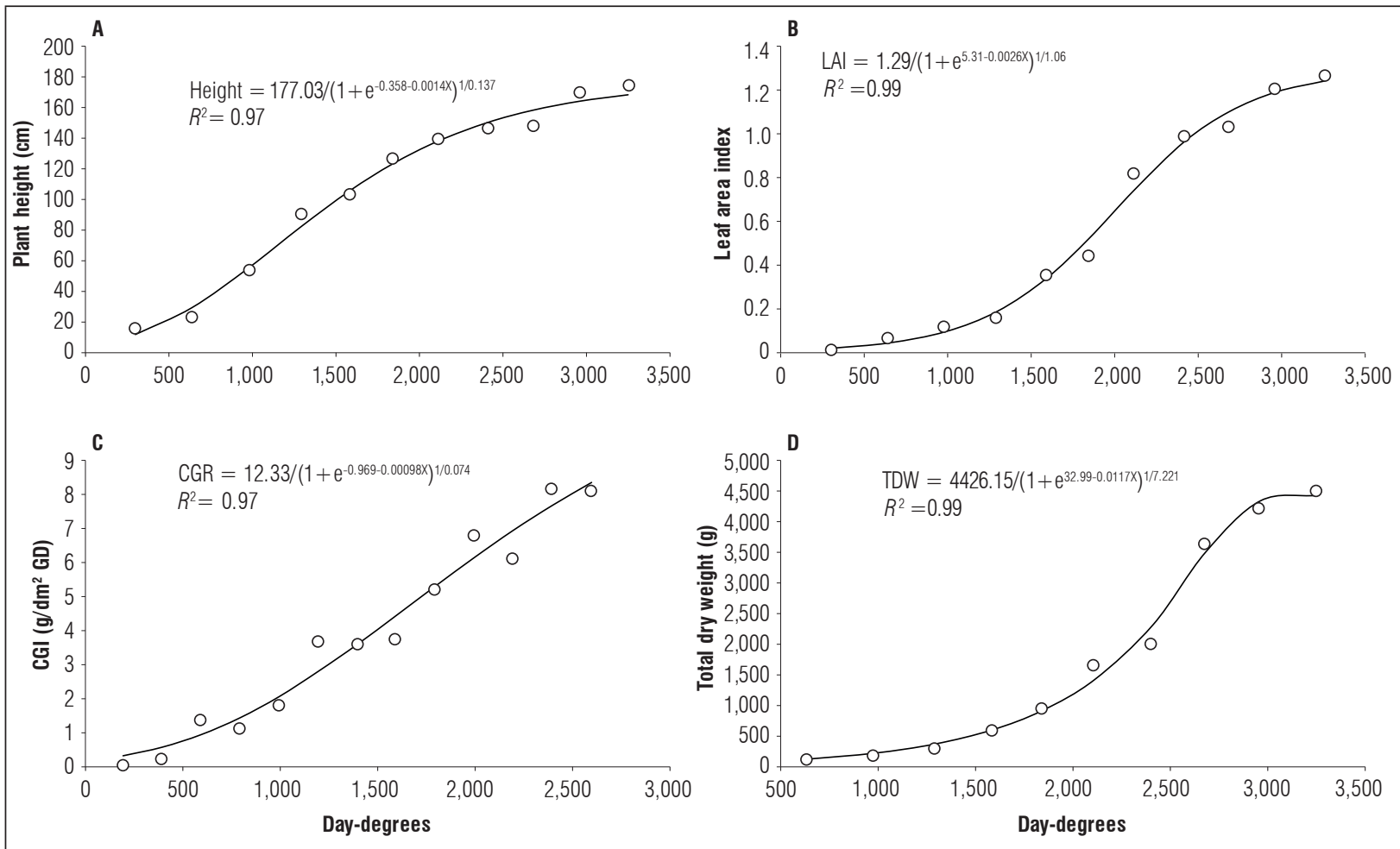

Figure 1. Dynamics of A) Height, B) Leaf area index, C) Crop growth index, and D) Total dry weight of S. quitoense plants grafted onto $S$. hirtum stocks, as a function of thermal time (DD). 
Total dry weight (TDW). Plants distribute their cumulative biomass between vegetative and reproductive structures according to the plant's priorities (Cardona et al., 2016). The total dry weight, including the dry weight of the different plant organs (roots, stems, leaves, flowers, and fruits), showed an initially slow growth; however, the TDW reached 4,487.5 g at 3,252 DD and the end of evaluations. The behavior of this variable was fit to Richards model with an $R^{2}=0.99$ (Fig. 1D).

The gradual and constant increase in dry weight of the grafted lulo plants agrees with reports by Medina et al. (2008). However, our results differ from earlier findings by Cruz et al. (2007) in non-grafted lulo plants, which showed reduced total biomass after 2,962 DD, caused by biotic factors such as Meloidogyne spp. and Fusarium sp., with higher incidence after eight months of planting.

Leaf dry weight (LDW). As shown in figure 2A, there was a constant increase in LDW until the end of the evaluation with a cumulative LDW of $697 \mathrm{~g}$ at 3,252 DD. The behavior of this variable was fit to Richards model $\left(R^{2}=0.98\right)$. At $640 \mathrm{DD}$, the LDW accounted for the largest fraction of the total dry weight, while, at $983 \mathrm{DD}$, it was exceeded by stem dry weight (SDW) and had a final contribution of $15.54 \%$. Similar results were reported by Cruz et al. (2007), who found that SDW exceeded LDW at 600 DD after planting.

Stem dry weight (SDW). The stems accounted for the largest fraction of the total dry weight of the lulo plants. Initially, the leaves contributed the most biomass but, by the end of the third evaluation, the stems showed the highest increase in dry matter, as compared to other organs (39.71\%). The cumulative stem dry weight increased to a maximum value of $1,782 \mathrm{~g}$ at $3,252 \mathrm{DD}$. This behavior was fit to Richards model with an $R^{2}=0.98$ (Fig. 2B). The same trend was described by Cruz et al. (2007), who reported that, in non-grafted $S$. quitoense, stems contributed the majority of dry biomass to the total dry weight. Di Benedetto and Tognetti (2016) stated that the aerial part:root ratio aids understanding of the partition of assimilates, and the ontogeny of each organ as a proportion of carbon accumulation is affected, which is

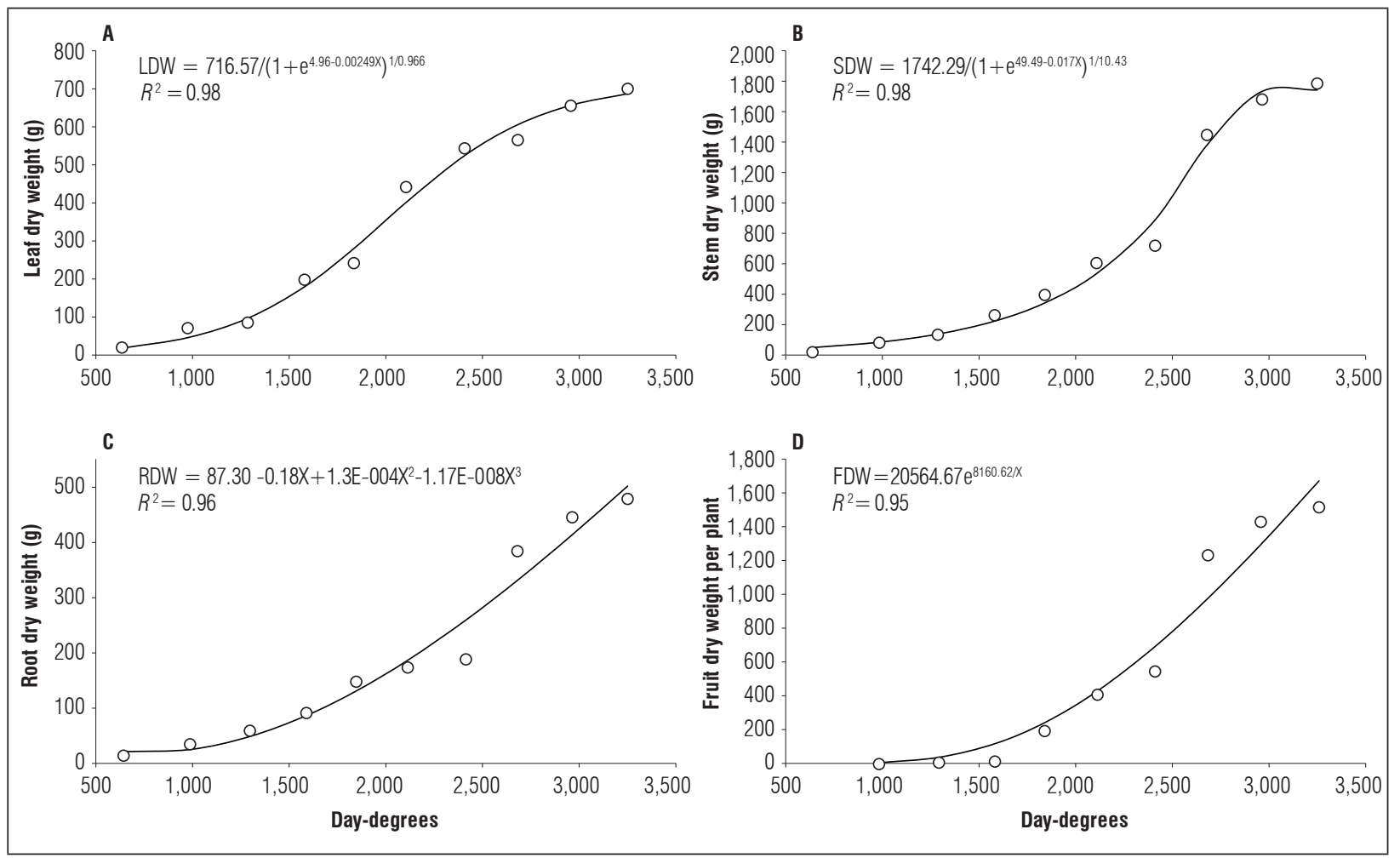

Figure 2. Behavior of A) leaf dry weight, B) stem dry weight, C) root dry weight, and D) fruit dry weight of lulo plants grafted onto $S$. hirtum stocks, as a function of thermal time. 
higher in stems than other organs (e.g. leaves) as time passes.

Root dry weight (RDW). Figure 2C shows a constant increase in RDW throughout the evaluation period, to a maximum of $473 \mathrm{~g}$ at $3,252 \mathrm{DD}$, which represented $10.56 \%$ of the total dry biomass. The RDW dynamics were fit to a cubic polynomial model $\left(R^{2}=0.96\right)$. The constant increase in RDW differed from other studies on non-grafted plants that reported a rapid decrease in RDW after two months because of sanitary issues caused by nematodes or Fusarium sp. (Cruz et al., 2007; Gelpud et al., 2010). A lower increase in biomass is due to a slower plant metabolic rate since active root tissue is suppressed and water and nutrient flow are mechanically disrupted (Jacquet et al., 2005).

Flower dry weight (FDW). The FDW showed a gradual increase up to $17.4 \mathrm{~g}$ at $3,252 \mathrm{DD}$, equivalent to $0.40 \%$ of the total dry weight. The cumulative flower dry matter was fit to a quadratic model $\left(R^{2}=\right.$ 0.98): $\mathrm{FDW}=-2.63+2.03 \mathrm{X}-0.025 \mathrm{X}^{2}$

Flower structures are short-lived in plants, and, on average, no more than one-third of flower buds contribute to fruit set. This observation agrees with Cruz et al. (2007) and Medina et al. (2008).

Fruit dry weight (FDW). Figure 2D shows a constant increase in FDW from onset of fruit production at 801 DD until the end of the experiment, reaching a FDW of $1,516 \mathrm{~g}$ at $3,252 \mathrm{DD}$. The dynamics of the dry fruit weight trend fit an exponential model $\left(R^{2}=0.95\right)$. The FDW was the second most significant fraction of the TDW, after SDW, because it contributed $33.78 \%$ of the total plant dry weight. This finding agrees with Medina et al. (2008), who reported that fruits of non-grafted lulo plants (Solanum quitoense var. quitoense) accounted for 25 to $30 \%$ of the total dry plant weight between 11 and 12 months after planting.

Yield (Y). The yield was one of the most relevant variables because it facilitates decisions based on cost-effectiveness. The harvest started at a cumulative thermal time of 2,464 DD and finalized at 3,252 $\mathrm{DD}$ after eight harvests. The yield was $6,503 \mathrm{~kg} \mathrm{ha}^{-1}$ by the end of the harvest. The fruit yield was $3.9 \mathrm{~kg} /$ plant, obtained from eight harvests of lulo plants grafted onto $S$. hirtum. These results agree with Silva et al. (2015), who reported a productivity of $6.0 \mathrm{~kg} /$ plant and fruits with a weight of $110 \mathrm{~g}$ in a promising S. quitoense genotype. Additionally, $30.67 \%$ of the yield included fruits with a polar diameter greater or equal to $65 \mathrm{~mm}, 53.18 \%$ corresponded to fruits with an equatorial diameter greater than $60 \mathrm{~mm}$ and less than $65 \mathrm{~mm}$, and $16.15 \%$ of fruits showed an equatorial diameter lower than $60 \mathrm{~mm}$.

\section{CONCLUSION}

Lulo plants (Solanum quitoense) grafted onto Solanum hirtum rootstocks needed a thermal time of $561 \mathrm{DD}$ to reach the flower bud stage, $715 \mathrm{DD}$ for anthesis, 801 DD for fruit set, and 2,464 DD to reach fruit ripening. Based on the cumulative thermal time, the dynamics of plant height, leaf area index, total dry weight, and total stem and leaf dry weight were fit to Richards model, while the crop growth index was fit to a Gaussian model. The root dry weight was fit to a third-degree polynomial model, the flower dry weight was fit to a quadratic model, and the fruit dry weight was fit to a modified exponential model. The yield was not affected by the grafting process; conversely, the crop population and productivity were maintained for a longer time.

Conflict of interests: The manuscript was prepared and reviewed with the participation of the authors, who declare that there exists no conflict of interest that puts at risk the validity of the presented results.

\section{BIBLIOGRAPHIC REFERENCES}

Agronet. 2020. Estadísticas agrícolas - lulo, año 2018. In: http://www.agronet.gov.co/estadistica/Paginas/default.aspx; consulted: January, 2020.

Aguilar-Campo, C., P. Juárez-López, I. Campos-Aguilar, I. Alia-Tejacal, M. Sandoval-Villa, and V. Martínez-López. 2015. Análisis de crecimiento y rendimiento de uchuva (Physalis peruviana L.) cultivada en hidroponía e invernadero. Rev. Chapingo Ser. Hortic. 24(3), 191-202. Doi: 10.5154/r.rchsh.2017.07.024

Almanza, P., P. Serrano, and O. Castro. 2008. Respuesta fisiológica del lulo (Solanun quitoense Lam.) a la fertilización orgánica en Tinjacá, Boyacá. Cultura Científica (6), 82-86.

Arizala, M., A. Monsalvo, Betancourth, C., Salazar, and C. Lagos. 2011. Evaluación de solanáceas silvestres como patrones de lulo (Solanum quitoense Lam) y su reacción a Fusarium sp. Rev. Cienc. Agric. 28(1), 147-160.

Barrientos, H., C. Del Castillo, and M. García, 2015. Análisis de crecimiento funcional, acumulación de biomasa y translocación de materia seca de ocho hortalizas 
cultivadas en invernadero. Rev. Investig. Innov. Agropecu. Recur. Nat. 2(1), 76-86.

Benítez, E., W. Viera, P. Garrido, and F. Flores. 2020. Current research on andean fruit crop diseases. pp. 387-401. In: Chong, P., D. Newman, and D. Steinmacher (eds.). Agricultural, forestry and bioindustry biotechnology and biodiscovery. Springer, Cham, Germany. Doi: 10.1007/978-3-030-51358-0_19

Browning, D., K. Snyder, and J. Herrick. 2019. Plant phenology: Taking the pulse of rangelands. Rangelands 41(3), 129-134. Doi: 10.1016/j.rala.2019.02.001

Cardona, W., L. Bautista, N. Flórez, and G. Fischer. 2016. Desarrollo de la biomasa y raíz en plantas de lulo (Solanum quitoense var. Septentrionale) en respuesta al sombrío y anegamiento. Rev. Colomb. Cienc. Hortic. 10(1), 53-65. Doi: 10.17584/rcch.2016v10i1.5124

Casiano, M. and F. Paz. 2018. Patrones espectrales de la fenología del desarrollo vegetativo y reproductivo de árboles de huizache (Acacia farnesiana (L.) Willd.). Terra Latinoam. 36(4), 393-409. Doi: 10.28940/terra. v36i4.417

Clements, C., J. Alwang, V. Barrera, and J.M. Dominguez. 2016. Graft is good: the economic and environmental benefits of grafted Naranjilla in the Andean region. Renew. Agr. Food Syst. 32(4), 306-318. Doi: 10.1017/ S174217051600020X

Criollo, H., J. Muñoz, J. Checa and W. Noguera. 2019. Initial growth of coffee (Coffea arabica L. var) castillo in the coffee zone of Nariño. Rev. Cienc. Agr., 36(E): 124137. Doi: 10.22267/rcia.1936E.112

Criollo, H., M. Perea, M. Toribio, and J. Muñoz. 2014. Effect of the combination of NAA, kinetin and sucrose on the induction of somatic embryogenesis in lulo (Solanum quitoense Lam.) Agron. Colomb. 32(2), 170-179. Doi: 10.15446/agron.colomb.v32n2.43861

Cruz, P., K. Acosta, J. Cure, and D. Rodríguez. 2007. Desarrollo y fenología del lulo Solanum quitoense var. septentrionale bajo polisombra desde siembra hasta primera fructificación. Agron. Colomb. 25(2), 288-298.

Di Benedetto, A. and J. Tognetti. 2016. Técnicas de análisis de crecimiento de plantas. Su aplicación a cultivos intensivos. Rev. Invest. Agropec. 42(3), 258-282.

Fischer, G. and L.M. Melgarejo. 2020. The ecophysiology of cape gooseberry (Physalis peruviana L.) - an Andean fruit crop. A. review. Rev. Colomb. Cienc. Hortíc. 14(1). Doi: 10.17584/rcch.2020v14i1.10893

Gelpud, C., E. Mora, C. Salazar, and C. Betancourth. 2010. Susceptibilidad de genotipos de Solanum spp. al nemátodo causante del nudo radical Meloidogyne spp. (Chitwood). Acta Agron. 60(1), 50-67.

González, O. and H. Salamanca. 2008. Unidades de suelo representativas de la zona cafetera colombiana. Centro Nacional de Investigaciones de Café - Cenicafé. Chinchina, Colombia.
Gallo, Y., L.F. Toro, H. Jaramillo, P.A. Gutiérrez, and M. Marín. 2018. Identificación y caracterización molecular del genoma completo de tres virus en cultivos de lulo Solanum quitoense) de Antioquia (Colombia). Rev. Colomb. Cienc. Hortic. 12(2), 281-292. Doi: 10.17584/ rcch.2018v12i2.7692

Jacquet, M., M. Bongiovanni, M. Martinez, P. Verschave, E. Wajnberg, and P. Castagnone. 2005. Variation in resistance to the root-knot nematode Meloidogyne incognita in tomato genotypes bearing the Mi gene. Plant Pathol. 54, 93-99. Doi: 10.1111/j.1365-3059.2005.01143.x

Jerez, E., R. Martín, D. Morales, and Y. Díaz. 2016. Análisis clásico del crecimiento en tres variedades de papa (Solanum tuberosum L.). Cultivos Tropicales 37(2), 79-87.

Jurado, J., L. Pérez., T. Lagos, and C. Benavides. 2013. Comportamiento agronómico de injertos de lulo de castilla Solanum quitoense Lam. en patrones de Solanum spp. Rev. Cienc. Agríc. 30(1), 54-64.

López-Cruz, I., A. Ramírez-Arias, and A. Rojano-Aguilar. 2005. Modelos matemáticos de hortalizas en invernadero: trascendiendo la contemplación de la dinámica de cultivos. Rev. Chapingo, Ser. Hortic. 11(2), 257-267. Doi: 10.5154/r.rchsh.2003.08.050

Luo, Q., M. Bange, and L. Clancy. 2014. Cotton crop phenology in a new temperature regime. Ecol. Model. 285, 22-29. Doi: 10.1016/j.ecolmodel.2014.04.018

Matzarakis, A., D. Ivanova, C. Balafoutis, and T. Makrogiannis. 2007. Climatology of growing degree days in Greece. Clim. Res. 34, 233-240. Doi: 10.3354/cr00690

Medina, C., E. Martinez, M. Lobo, and M. Vargas. 2008. Distribución de la materia seca durante la ontogenia del lulo (Solanum quitoense Lam.) a plena exposición solar en el bosque húmedo montano bajo del oriente Antioqueño, Colombia. Rev. Fac. Nac. Agron. Mede1lin 61(1), 4256-4268.

Muñoz, J., L. Rodríguez, and L. Bermúdez. 2013. Análisis de competitividad del sistema de producción de lulo (Solanum quitoense Lam.) en tres municipios de Nariño. Rev. Colomb. Cienc. Hortic. 7(2), 173-185. Doi: 10.17584/rcch.2013v7i2.2233

Muñoz, L. 2010. Evaluación Agronómica de materiales de lulo Solanum sp., frutal de alto potencial para zonas tropicales. MSc thesis. Faculty of Agriculture Sciences, Universidad Nacional de Colombia, Palmira, Colombia.

Navarrete, X., R. Lenin, P. Viteri, and W. Viera. 2018. Parasitism of the root knot nematode Meloidogyne incognita (Kofoid and White) chitwood in five wild Solanaceae species. Rev. Fac. Nac. Agron. Medellin 71(1), 83678373. Doi: 10.15446/rfna.v71n1.67122

Noboa, M. and W. Viera. 2020. Biology of Neoleucinodes elegantalis (Guenée 1854) (Lepidoptera: Crambidae): pest of economic importance of naranjilla, an Amazonian fruit of Ecuador. Int. J. Trop. Insect Sci. 40, 717-722. Doi: 10.1007/s42690-020-00118-7 
Ochoa-Vargas, L., H. Balaguera-López, G. Ardila-Roa, E. Pinzón-Sandoval, and J. Álvarez-Herrera. 2016. Crecimiento y desarrollo del fruto de lulo (Solanum quitoense Lam.) en el municipio de San Antonio del Tequendama (Colombia). Corpoica Cienc. Tecnol. Agropec. 17(3), 347-359. Doi: 10.21930/rcta.vol17_num3_art:512

Poorter, H. and L. Sack. 2012. Pitfalls and possibilities in the analysis of biomass allocation patterns in plants. Front. Plant Sci. 3(259), 259. Doi: 10.3389/ fpls.2012.00259

Pulido, S., C. Bojaca, M. Salazar, and B. Chaves. 2008. Node appearance model for lulo (Solanum quitoense Lam.) in the high altitude tropics. Biosyst. Eng. 12(1), 383-387. Doi: 10.1016/j.biosystemseng.2008.09.009

Rincón, N., M. Olarte, and J. Pérez. 2012. Determinación del área foliar en fotografías tomadas con una cámara Web, un teléfono celular o una cámara semiprofesional. Rev. Fac. Nac. Agron. Medellin 65(1), 6399-6405.

Rojas, S., J. García, and M. Alarcón. 2004. Propagación asexual de plantas. Conceptos básicos y experiencias con Especies Amazónicas. Corpoica, Bogota.

Sacks, W. and J. Kucharika. 2011. Crop management and phenology trends in the U.S. Corn Belt: Impacts on yields, evapotranspiration and energy balance. Agric. For. Meteorol. 151, 882-894. Doi: 10.1016/j. agrformet.2011.02.010

Sánchez-Reinoso, A.D., Y. Jiménez-Pulido, J.P. Martínez-Pérez, C.S Pinilla, and G. Fischer. 2019. Parámetros de fluorescencia de la clorofila y otros parámetros fisiológicos como indicadores del estrés por anegamiento y sombrío en plántulas de lulo (Solanum quitoense var. septentrionale). Rev. Colomb. Cienc. Hortic. 13(3), 325-335. Doi: 10.17584/rcch.2019v13i3.10017

Serna, F. 2017. Evaluación fenológica de híbridos de lulo de castilla (Solanum quitoense Lam.) en dos ambientes de cultivo de la ecorregión eje cafetero de Colombia. Undergraduate thesis. Escuela de Ciencias Agrarias Pecuarias y del Medio Ambiente, Universidad Nacional Abierta y a Distancia, Armenia, Colombia.

Silva, W., P. Gómez, W. Viera, A. Sotomayor, P. Viteri, and L. Ron. 2015. Evaluación de líneas promisorias de naranjilla para mejorar la calidad de fruta. Rev. Cient. Ecuat. 3, 23-30. Doi: 10.36331/revista.v3i1.21

Taiz, L., E. Zeiger, I. Max, and A. Murphy. 2017. Fisiologia e desenvolvimento vegetal. $6^{\text {th }}$ ed. ArtMed Editora, Porto Alegre, Brazil.

Vargas, Y., J. Nicolalde, W. Alcivar, L. Moncayo, C. Caicedo, J. Pico, L. Ron, and W. Viera. 2018. Response of wild Solanaceae to Meloidogyne incognita inoculation and its graft compatibility with tree tomato (Solanum betaceum). Nematrópica 48(2), 126-135.

Viteri, D., M. Revelo, J. Ochoa, F. Leon, Y. Vasquez, and M. Posso. 2006. Comportamiento agronómico de la naranjilla comun var. Baeza (Solanum quitoense Lam.), injertada en solanaceas silvestres con resistencia a Fusarium oxysporum y Meloidogyne incognita, en el noroccidente de Pichincha. Instituto Nacional de Investigaciones Agropecuarias, INIAP, Quito. 


\section{Hernando Criollo Escobar}

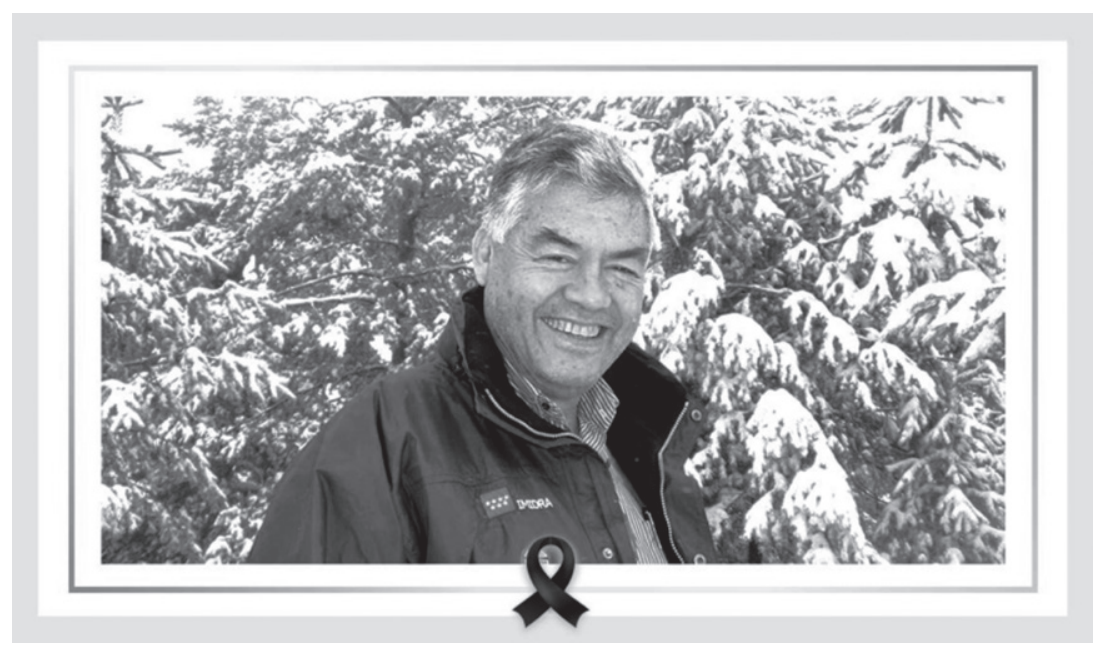

"La muerte es el comienzo de una historia de amor que viviremos eternamente con Dios y con los seres que amamos. Muchas personas fallecen diariamente en el mundo, pero aquellas que por sus obras trascienden y nos reconcilian con la humanidad, son pocas".

El Doctor HERNANDO ARTEMIO CRIOLLO ESCOBAR, fue fundador e integrante del Grupo de Investigación en Producción de Frutales Andinos. Dedicó veinte años de su vida académica y científica a la producción de conocimiento, a estructurar y fomentar proyectos de investigación, con los cuales impulsó el crecimiento social y económico de la agricultura y la educación superior del departamento de Nariño.

El Grupo de Investigación en Producción de Frutales Andinos reconoce y exalta los innumerables aportes realizados por el Doctor HERNANDO ARTEMIO CRIOLLO ESCOBAR en la educación, investigación y extensión rural, los cuales fueron un factor de desarrollo para las ciencias agrarias y un aporte significativo a la acreditación de los programas de Ingeniería Agronómica e Ingeniería Agroforestal de la Facultad de Ciencias Agrícolas.

El Grupo de Investigación en Producción de Frutales Andinos rinde homenaje póstumo a un hombre destacado, sensible y especial profesional de las ciencias agrarias, de vocación $y$ rigor científico indiscutible.

Su admirable dedicación al trabajo científico lo hizo merecedor de varias distinciones, fue autor de 69 artículos científicos, tres libros de investigación, tres libros de texto y asesor de innumerables tesis de pregrado y postgrado.

El Grupo de Investigación en Producción de Frutales Andinos lamenta profundamente el sensible fallecimiento de su fundador, Dr. HERNANDO ARTEMIO CRIOLLO ESCOBAR y le expresa a su Señora madre Rosita Escobar, a sus hermanos Rubiela y Rodrigo Criollo Escobar, a su esposa Johana Muñoz, a sus hijos Paola Fernanda, Claudia Patricia, Karime Ivonne, Ruth Amanda, Edgar Hernando, Luis Carlos y Andrés Felipe Criollo, un profundo sentimiento de condolencias.

Se firma en San Juan de Pasto, el primero de septiembre del dos mil veinte.

TULIO CÉSAR LAGOS BURBANO

Líder del Grupo de Investigación en la Producción de Frutales Andinos.

\section{Para un amigo \\ El alma sufre \\ Deja las flores que \\ adornaron la vida. \\ Comienza el viaje}

El camino se hace cierto

La luz brillante

marca el ascenso

A lo lejos, lo espera con brazos abiertos el gran anfitrión

El guia el destino del alma hacia su hamaca de hilos de seda

Abierto el cielo inmenso

Enmudece el rumor terrenal

El susurro del viento celestial alegra al viajero que pronto encontrará su destino.

Nubes blancas adornan su llegada,

Música al alma, es el gran premio para el viajero

Hasta pronto querido hermano. 